\title{
A serum fucose-binding lectin (DIFBL) from adult Dicentrarchus labrax is expressed in larva and juvenile tissues and contained in eggs
}

\author{
M. Giovanna Parisi • Matteo Cammarata • \\ Gigliola Benenati • Giuseppina Salerno • \\ Valentina Mangano • Aiti Vizzini • Nicolò Parrinello
}

Received: 7 January 2010 /Accepted: 31 May 2010 /Published online: 3 July 2010

(C) Springer-Verlag 2010

\begin{abstract}
The purification, cloning, sequencing, molecular properties and expression of a fucose-binding lectin from the serum of Dicentrarchus labrax (DIFBL) have been previously reported. We now describe the distribution and expression of DIFBL during fish ontogeny. Immunohistochemistry and in situ hybridization assays were carried out at various developmental stages (from 10 days posthatching larvae to juveniles). Another fucose-binding lectin, similar to DIFBL in biochemical, immunochemical and agglutinating properties, was extracted and purified from eggs and appeared to be localized in the embryo yolk sack residual. DIFBL was found in columnar and goblet cells of the intestinal epithelium of larvae (from 20 days post-hatching) and juveniles and in parenchymal tissue of juveniles. DIFBL mRNA and protein were detected in the intestinal epithelium and in hepatocytes. An amplification product from degenerate primers indicates that lectin isotypes with DlFBL epitopes are expressed in eggs and embryos. Whether the lectin fraction isolated from eggs and embryos includes DIFBL of maternal origin remains unclear.
\end{abstract}

Keywords F-type lectin · Ontogeny · In situ hybridization · Immunohistochemistry · Dicentrachus labrax (Teleostei)

M. G. Parisi • M. Cammarata • G. Benenati · G. Salerno •

V. Mangano $\cdot$ A. Vizzini $\cdot$ N. Parrinello $(\triangle)$

Laboratory of Marine Immunobiology,

Department of Animal Biology, University of Palermo,

Via Archirafi 18,

90123 Palermo, Italy

e-mail: nicpar@unipa.it

\section{Introduction}

Animal lectins are proteins or glycoproteins that bind polysaccharides, glycoconjugate and membrane glycoproteins and some of them are involved in innate and adaptive immunity including cell communication, agglutination, proliferation, opsonization, signal transduction and apoptosis (Wassarman 1987; Kamiya et al. 2002; Kilpatrick 2002; Suzuki et al. 2003; Dong et al. 2004). Vertebrate lectins are mediators of non-self recognition in various biological processes (Kilpatrick 2002; Sharon and Lis 2004; Arason 1996; Hoffmann et al. 1999), identify and stimulate the uptake of pathogens by phagocytes, initiate complementmediated cell lysis and enhance natural killer cell activity (Andersen et al. 1991; Turner 1996). On the basis of sequence similarities, sugar specificity and the structure of the carbohydrate recognition domain (CRD), animal lectins have been included into several protein families (Kilpatrick 2000). Recently, fucose-binding lectins (FBLs) have been identified as components of a novel lectin family characterized by an F-type protein fold shared with carbohydratebinding proteins found at various evolutionary branches, from bacteria to vertebrates (Vasta et al. 2004).

Fish lectins have been isolated and characterized from the serum of various species (Hoover et al. 1998; Ottinger et al. 1999; Russel and Lumsden 2005; Odom and Vasta 2006). Their ability to bind terminal sugars on glycoproteins and glycolipids makes them part of an important recognition pattern of receptors in innate immunity (Fock et al. 2000, 2001; Russel and Lumsden 2005). The most widely known animal FBLs have been isolated from the serum of diverse teleostean species (Honda et al. 2000; Cammarata et al. 2001, 2007; Bianchet et al. 2002; Odom 
and Vasta 2006; Salerno et al. 2009) and their activity against pathogenic bacteria has been shown (Salerno et al. 2009).

With regard to their localization in fish tissue, immunohistochemical studies have disclosed that FBLs are present in parenchymal hepatocytes and in gill exocrine mucous cells of Anguilla japonica (Honda et al. 2000) and their transcript is expressed in liver, gill and intestine. In Morone saxatalis, their transcript has primarily been identified in the liver, and at a relatively lower level, in the gill, skin, brain, heart, intestine, skeletal muscle and posterior kidney (Odom and Vasta 2006).

Recently, FBLs from sea bass Dicentrarchus labrax (DIFBL; Salerno et al. 2009) and sea bream Sparus aurata (SaFBL; Cammarata et al. 2007) have been purified by affinity chromatography on a fucose-agarose column. Sequence analysis has revealed that they are composed of two tandem domains provided with a fucose carbohydrate recognition sequence motif (F-CRDs) and has demonstrated that they are members of the FBL family. Cloning, sequencing, immunohistochemical and in situ hybridization methods have revealed that sea bass hepatocytes, globet cells from the gut and, at a lower level, head kidney and gonads express and produce DlFBL (Salerno et al. 2009). In addition, the opsonic activity of purified serum DlFBL has been demonstrated against Gram-negative bacteria.

In the present study, we show, for the first time, that fish F-lectins can be expressed during ontogenesis, mainly during post-hatching larval development. In addition, DIFBL from fertilized and unfertilized sea bass egg homogenates has been purified and partially characterized.

\section{Materials and methods}

Fish

Adult D. labrax specimens were provided by the Italittica (Trapani Italy) farm and maintained in aquaria at $18-20^{\circ} \mathrm{C}$ ( 8 ppm salinity and $37 \mathrm{ppm}$ oxygen in sea water). Gut and liver were excised from anaesthetized fish treated with an overdose of $0.03 \%$ 3-aminobenzoic acid ethyl ester (MS222; Sigma). The excised organs were immediately examined or frozen on dry ice and stored at $-80^{\circ} \mathrm{C}$. Larvae, post-hatching larvae and juveniles were anaesthetized with $0.05 \%$ MS222 in seawater. Tissue and developmental stages were fixed for processing by histological methods or were held in RNA-later solution at $-80^{\circ} \mathrm{C}$.

\section{Developmental stages}

Unfertilized eggs, embryos collected at about $70-72 \mathrm{~h}$ after fertilization (hpf) and larvae of D. labrax were obtained from the Oro Vivo dell'Adriatico fish farm (Brindisi, Italy). According to the sorting criteria reported by Barnabé (1980), embryos at 70-72 hpf completed morphogenesis, pigmentation and elongation in the egg envelope before metamerization. Based on their morphological characteristics, the following four developmental stages were identified: (1) pre-larvae at $1-5$ days post-fertilization, (2) larvae at 6-25 days post-hatching (dph), (3) larvae at 26$49 \mathrm{dph}, 4)$ juveniles at $50 \mathrm{dph}$ with visible flakes and adult morphology.

Preparation of embryos in toto

Before fixation in Bouin's solution, chorion and yolk sack were removed from fertilized eggs by surgical microscissors. Embryos were treated with $85 \%$ and then with $95 \%$ ethanol solution for $5 \mathrm{~min}$. Subsequently, membranes were permeabilized with $2 \mathrm{mM}$ EDTA, $100 \%$ methanol and rehydrated with alcohol at increasing concentrations. After washes in phosphate-buffered saline with Tween (PBS-T: $1 \mathrm{M} \mathrm{Na}_{2} \mathrm{HPO}_{4}, 1 \mathrm{M} \mathrm{NaH}_{2} \mathrm{PO}_{4}, 1.5 \mathrm{M} \mathrm{NaCl}, 0.1 \%$ Tween 20) as a blocking solution, primary antibody (anti-DlFBL) and secondary antibody (a sheep anti-rabbit IgG-alkalinephosphatase conjugate) were added according to the previously described protocol (Cammarata et al. 2001).

\section{Histology}

Embryos and larvae (gut and liver) fixed in Bouin's solution (15:5:1 picric acid saturated aqueous solution: formaldehyde:glacial acetic acid) for $24 \mathrm{~h}$ were rinsed and stored in $70 \%$ ethanol. After dehydration, the tissues were embedded in paraffin. Serial transverse or longitudinal sections of tissue $(4 \mu \mathrm{m})$ or of eggs $(7 \mu \mathrm{m})$ cut on a microtome (Leica RM2035) were mounted on poly-Llysine-coated microscope slides.

Liver histological sections were stained by using the method of Mallory (1936) for $30 \mathrm{~min}$. Gomori stain (1950) was used to examine the intestinal epithelium, goblet cells and various development stages. Dehydrated tissue sections were treated with Weigert's iron haematoxylin (Weigert 1904) and then with the trichrome staining procedure (Thompson 1966). After a wash in $0.5 \%$ acetic acid, histological sections were dehydrated in alcohol, cleared in xylene, mounted in a synthetic resin (Eukitt) and examined under a light microscope (Leica DMRE).

Immunohistochemistry

Histological sections were pre-incubated for $1.5 \mathrm{~h}$ at room temperature with $3 \%$ bovine serum albumin (BSA) in PBS$\mathrm{T}$ and treated at $4{ }^{\circ} \mathrm{C}$ overnight with anti-DlFBL antibodies (1:800 in PBS-T, 0.1\% BSA). Following washes with PBS- 
$\mathrm{T}$, bound antibodies were detected ( $1.5 \mathrm{~h}$ treatment) with a sheep anti-rabbit IgG-alkaline-phosphatase conjugate $(1: 15,000$ in PBS-T, $0.1 \%$ BSA). After exhaustive washes with PBS-T, the enzyme reaction was visualized by means of a BCIP/NBT (5-bromo-4-chloro-3-indolyl-phosphate/ nitroblue tetrazolium) liquid substrate system. The following controls were performed: (1) the anti-DlFBL antiserum was replaced with pre-immune rabbit serum, (2) the primary (anti-DlFBL) antibodies were replaced with PBS, (3) the anti-DlFBL antiserum was replaced with absorbed anti-DIFBL antiserum.

In situ hybridization

Antisense (AS) and sense (S) probes were synthesized from the DIFBL cDNA clone and digoxigenin (DIG)labeling was performed with the DIG-UTP in vitro transcription kit (Roche Diagnostics, Meylan, France). After plasmid amplification, DNA was purified by using a QUIAquick Gel Extraction Kit and specific primers. Tissue sections $(5 \mu \mathrm{m})$ were prepared on coated glass slides and in situ hybridization was performed according to Alonso et al. (2004). Sections were deparaffinized, washed twice in PBS-T and digested with proteinase $\mathrm{K}$ ( $1 \mu \mathrm{l} / \mathrm{ml}$ in PBS-T). The reaction was blocked by stop solution (2 $\mathrm{mg} / \mathrm{ml}$ glycine in PBS-T). After washes in PBS-T, sections were treated with $4 \%$ formaldehyde in PBS-T followed by pre-hybridization with the hybridization solution $(50 \%$ formamide, $5 \times$ standard sodium citrate [SSC], $50 \mathrm{~g} / \mathrm{ml}$ heparin, $500 \mu \mathrm{g} / \mathrm{ml}$ yeast tRNA, $0.1 \%$ Tween 20) at $42^{\circ} \mathrm{C}$ for $1 \mathrm{~h}$ and then treatment with $15 \%$ AS probe in hybridization solution at $42^{\circ} \mathrm{C}$ overnight. Washes were performed once in PBS-T at $42^{\circ} \mathrm{C}$ for $10 \mathrm{~min}$ and twice in $0.3 \% \mathrm{SSC}, 20 \times 1 \%$ Tween 20 . Sections were incubated at room temperature with horse serum $(2 \%$ in PBS-T) and with anti-DIG Fab-antibody (Roche; diluted $1: 100$ in the horse serum solution) for $1 \mathrm{~h}$ at room temperature. Finally, the sections were incubated in BCIP/ NBT. Controls were performed by the corresponding sense cRNA $(1 \mu \mathrm{g} / \mathrm{ml})$.

\section{Specific antibody}

Specific antibodies were prepared and assayed according to Cammarata et al. (2001). In brief, antibodies to DlFBL were raised in rabbit by Medprobe (Norway) by means of four injections of $50 \mu \mathrm{g} 34-\mathrm{kDa}$ lectin isolated from SDSpolyacrylamide gels.

To check for specificity, the antiserum was absorbed with $40 \mu \mathrm{g}$ DIFBL in $100 \mu \mathrm{l}$ PBS overnight at $4^{\circ} \mathrm{C}$ and centrifuged at $27,000 \mathrm{~g}$ for $30 \mathrm{~min}$ at $4^{\circ} \mathrm{C}$. The specificity was checked by immunoblotting. Neither preimmune nor absorbed sera showed any reaction with the antigen.
Haemagglutination assay

Haemagglutination activity (HA) of two-fold serial dilutions of the sample was assayed in a 96-well microtitre $U$ plate by using a $1 \%$ rabbit erythrocyte suspension $(\mathrm{RBC})$ in PBS (PBS-E: $6 \mathrm{mM} \mathrm{KH} \mathrm{PO}_{4}, 0.11 \mathrm{mM} \mathrm{Na}_{2} \mathrm{HPO}_{4}, 30 \mathrm{mM}$ $\mathrm{NaCl}, \mathrm{pH}$ 7.4). Erythrocytes were supplied by the Istituto Zooprofilattico della Sicilia (Palermo, Italy) and maintained in sterile Alsever's solution (27 mM sodium citrate, $115 \mathrm{mM}$ D-glucose, $18 \mathrm{mM}$ EDTA, $336 \mathrm{mM} \mathrm{NaCl}$ in distilled water, $\mathrm{pH}$ 7.2). The reaction mixture was preformed in TRIS-buffered saline (TBS; see below) and enriched with $1 \% \mathrm{RBC}$ in TBS containing $0.1 \%(\mathrm{w} / \mathrm{v})$ gelatin. Twenty five microliter lectin preparation was mixed with an equal volume of RBC suspension and incubated at $37^{\circ} \mathrm{C}$ for $1 \mathrm{~h}$. To examine divalent cation requirements for $\mathrm{HA}, \mathrm{CaCl}_{2}$ or $\mathrm{MgCl}_{2}$ was added in the $\mathrm{HA}$ medium to obtain a 5-10 $\mathrm{mM}$ final concentration. The haemagglutination titre (HT) was recorded as the reciprocal of the highest dilution showing complete agglutination.

\section{Purification of DIFBL}

DIFBL from serum was purified as previously reported (Cammarata et al. 2001) according to a method of Honda et al. (2000). To isolate proteins, unfertilized eggs and 70-hpf embryos suspended in $20 \mathrm{mM}$ TRIS-HCl buffer ( $\mathrm{pH} 7.4$ ) containing a proteases inhibitor cocktail were homogenized on ice by using a Potter homogenizer for $10 \mathrm{~min}$. To remove lipid and insoluble materials, the sample was centrifuged at $13,000 \mathrm{~g}$ for $30 \mathrm{~min}$ at $4^{\circ} \mathrm{C}$. The supernatant was removed and stored at $-80^{\circ} \mathrm{C}$.

Briefly, 70-hpf embryo crude extract diluted in TBS to obtain $10-20 \mathrm{mg} / \mathrm{ml}$ protein content, was dialyzed against TBS (50 mM TRIS-HCl, $0.15 \mathrm{M} \mathrm{NaCl}, \mathrm{pH}$ 7.4), centrifuged at $10,000 \mathrm{~g}$ for $30 \mathrm{~min}$ and passed through a $5-\mathrm{ml} \mathrm{L}$ fucose-agarose column (Pierce). The column was washed with $1.0 \mathrm{M} \mathrm{NaCl}$, followed by TBS (10 volumes) at a flow rate of $0.2 \mathrm{ml} / \mathrm{min}$. DIFBL elution was carried out with $20 \mathrm{ml} 50 \mathrm{mM} \mathrm{L}$-fucose in TBS at the same flow rate, monitored by absorbance at $280 \mathrm{~nm}$. Fractions $(2 \mathrm{ml})$ were collected, pooled $(0.04 \mathrm{mg} / \mathrm{ml}$ protein content $)$ and dialyzed in TBS $(\mathrm{pH} 7.4)$ to be tested for HA with rabbit erythrocytes. The fractions exhibiting the highest activity were pooled and stored at $-80^{\circ} \mathrm{C}$.

SDS-polyacrylamide gel electrophoresis

SDS-polyacrylamide gel electrophoresis (SDS-PAGE) was performed on $10 \%$ slab gel by the method of Laemmli (1970). After electrophoresis, protein bands were stained with Coomassie Brilliant Blue R250 (Sigma). Relative molecular weights of the protein bands were determined by 
using molecular weight markers: albumin, bovine serum $(66.0 \mathrm{kDa})$, ovalbumin $(45.0 \mathrm{kDa})$, glyceraldehyde-3phosphate dehydrogenase $(36.0 \mathrm{kDa})$, carbonic anhydrase $(29.0 \mathrm{kDa})$ and trypsinogen $(24.0 \mathrm{kDa})$.

Carbohydrate specificity of purified fractions

Inhibition assays of HA towards RBC were performed in the presence of saccharides as potential inhibitors of lectin binding. Assays were carried out by using decreasing concentrations (starting from $100 \mathrm{mM}$, in TBS, $\mathrm{pH}$ 7.4) of L-fucose, rhamnose, D-galactose, D-glucose, D-mannose, $\mathrm{N}$-acetyl-galactosamine, lactose and maltose. The mixture was incubated for $20 \mathrm{~min}$ at room temperature before the erythrocyte suspension was added. The highest dilution of sugar leading to agglutination inhibition was recorded.

Protein content estimation

To estimate protein content, the method of Bradford (1976) was used with BSA (ranging from $0.1 \mathrm{mg} / \mathrm{ml}$ to $10 \mathrm{mg} / \mathrm{ml}$ ) as a standard.

Immunoblotting analysis

Proteins separated by SDS-PAGE (10\%) were electroblotted onto a nitrocellulose membrane. The gels were prepared in blotting buffer $(20 \mathrm{mM}$ TRIS-HCl, $192 \mathrm{mM}$ glycine, $10 \%$ methanol, $\mathrm{pH} 8.8$ ) and a semi-dry blotting bath (Bio-Rad Laboratories) was used $\left(0.8 \mathrm{~mA} / \mathrm{cm}^{2}\right.$ for $75 \mathrm{~min})$. The filter membrane was soaked in blocking buffer (PBS containing 3\% BSA and 1\% Tween 20), incubated with anti-DlFBL antibodies (1:400 in washing buffer, $0.1 \% \mathrm{BSA}$ ) for $1 \mathrm{~h}$, washed with blocking buffer, and incubated with sheep anti-rabbit IgG-alkalinephosphatase conjugate $(1: 15,000$ in washing buffer, $0.1 \%$ BSA) for $1 \mathrm{~h}$. Finally, the nitrocellulose membranes were washed with PBS-Tween $20(3 \times 15 \mathrm{~min})$ and developed with the BCIP/NBT liquid substrate system.

Preparation of DlFBL cDNAs from embryos and adult liver

Total RNA was extracted from $70 \mathrm{hpf}$ embryos or the liver of adult fish by using an RNAqueous TM-Midi Kit purification system (Ambion) according to manufacturer's instructions. To obtain the template for the polymerase chain reaction (PCR), the RNA was reverse-transcribed with a Ready-to-Go T-primed first-strand by using random primers (Amersham Biosciences). PCR amplification was carried out with a combination of DIFBL primers $(1 \mathrm{mM})$, viz. sense Dl342.F (5' GTTCTAACCAGGAAGCAGGA ATA3') and antisense Dl342.R (5'TTTTGTTTTGTTTGC GTACATTC3') designed from the DIFBL nucleotide sequence (AC EU877448). In order to detect isotypes (Odom and Vasta 2006), the following degenerate primers designed from the conserved amino acid sequence in fish (Perciformes) were used: P1.F (5'-dCAAAGCTTTAYAA CTAYAARAACGTNGC-3'); antisense P2.R (5'dTCGAA TTCGTNACGATRTANGGCTC-3'). Thermal cycling was performed with an MJ Research DNA engine PTC-100. DNA was denatured at $94^{\circ} \mathrm{C}$ for $3 \mathrm{~min}$, followed by the annealing of primers at $37^{\circ} \mathrm{C}$ for $30 \mathrm{~s}$ and by three-step cycles ( 35 cycles) of $94^{\circ} \mathrm{C}$ for $30 \mathrm{~s}, 50^{\circ} \mathrm{C}$ for $30 \mathrm{~s}$ and $72^{\circ} \mathrm{C}$ for $1 \mathrm{~min}$, and further extended at $72^{\circ} \mathrm{C}$ for $10 \mathrm{~min}$. The PCR products were analysed by electrophoresis on agarose gel containing ethidium bromide.

\section{Chemicals}

Unless otherwise reported, all chemicals and products were from Sigma, Aldrich (USA).

\section{Results}

DIFBL in developmental stages

In 70-hpf embryos examined in toto, positive immunohistochemical reaction was localized in granules of the residual yolk sack adherent to the ventral portion (Fig. 1a, b).

To identify larval tissues, histological sections treated with Mallory or Gomori stain were examined (Fig. 2: several stages, Fig. 3a, f). As observed in Fig. 2b, at the 10-dph larval stage, a rare and unclear immunoreaction was observed, whereas at the 20-dph larval stage, DIFBL was localized in the extracellular matrix of gut columnar epithelium. At the post-larval stage ( 25 and $36 \mathrm{dph}$ ), in addition to the columnar epithelium, positive goblet cells were found among the cells of the intestinal epithelium. In 50-dph juveniles, the same positive cells were found interposed between absorbent cells of the gut columnar epithelium (Fig. 3b) and liver parenchymal cells (Fig. 3g).

Antibody reaction was not observed in control sections or by using the antiserum absorbed with purified DIFBL (Fig. 2d, i, n, s: gut at 10, 20, 25, 36 dph, respectively; Fig. 3d, i: gut and liver at $50 \mathrm{dph}$ ).

DlFBL transcript is expressed at late developmental stages

When larvae at 10 and $20 \mathrm{dph}$ were examined by in situ hybridization, no signal was recognized and DIFBL mRNA was only found in the gut cells at 25 and $36 \mathrm{dph}$ (Fig. 2c, h, $\mathrm{m})$. In 50-dph juveniles, the nuclei of columnar intestinal cells and liver parenchyma showed the DIG-riboprobe (Fig. 3c, h). The specificity of the DIFBL labelling assay 
Fig. 1 Immunohistochemical staining of a caudal section of a 70-hpf embryo of Dicentrarchus labrax with polyclonal primary antibodies raised against a fucose-binding lectin from the serum of D. labrax (DIFBL). a Immunohistochemistry reaction in yolk sac granules ( $Y S G$, arrows) in an embryo caudal section $(C P)$. Bar $20 \mu \mathrm{m}$. b Higher magnification of granules after anti-DlFBL reaction in the caudal residual yolk sac. Bar $50 \mu \mathrm{m}$

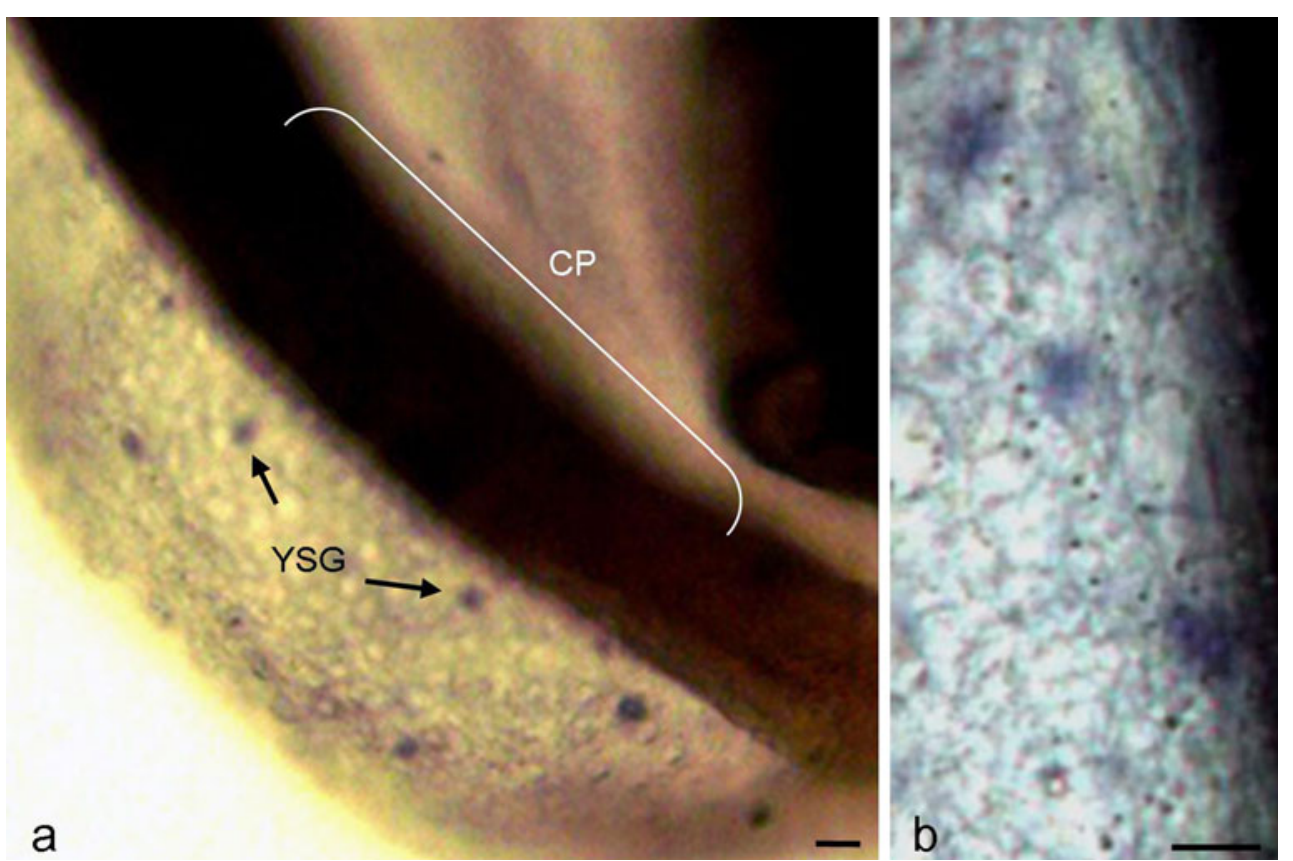

was established by treating the histological sections with the sense probe as shown in Fig. 2e, j, o, t at 10, 20, 25, $36 \mathrm{dph}$, respectively, and in Fig. 3e, j at $50 \mathrm{dph}$.

DIFBL is contained in eggs and embryos

Unfertilized eggs and embryo extracts displayed an HT ranging from 1:64 to 1:256 depending on sample preparations. This activity was calcium-independent, not affected by the addition of $\mathrm{CaCl}_{2}$ or $\mathrm{MgCl}_{2}$ (final concentration of $10 \mathrm{mM}$ ) to the samples (1:128 HT), and completely inhibited by a final fucose concentration of 10-25 mM.

To characterize egg and embryo DlFBLs, they were isolated by affinity chromatography. A typical embryo DlFBL purification profile on L-fucose-agarose is shown in Fig. 4. The HT of the separated fractions (peak 2, 27-34 fractions pooled) against rabbit erythrocytes ranged from $1: 16$ to $1: 32$; activity was abolished by adding L-fucose (12.5 mM), lactulose $(100 \mathrm{mM})$, mannose $(100 \mathrm{mM})$ and melibiose (100 mM ). No significant differences between egg and embryo chromatographic profiles and between HT profiles were found.

The purified embryo fraction (EDlFBL) analysed by SDS-PAGE (10\%) contained a single 34-kDa band under reducing conditions, whereas in the absence of $\beta$ mercaptoethanol, the band-size decreased to $30 \mathrm{kDa}$ (Fig. 5a). The 34-kDa protein reacted with the polyclonal anti-adult DlFBL antibodies in a Western blotting assay; the results indicated that EDIFBL shared epitopes with adult DIFBL (Fig. 5b). The same results were obtained when the purified fraction of unfertilized eggs was analysed (Fig. 5a, b). The absence of any band on using the absorbed antiserum established the specificity of the reaction (not shown).

Since reverse transcription and PCR amplification (D1342.F and D1342.R specific primers) of adult liver cDNA led to a single 800-bp band being disclosed by agarose gel electrophoresis (Fig. 5c, lane 2), an attempt to identify a PCR amplification product was carried out. However, no band was observed on analysing egg and embryo preparations (Fig. 5c, lane 1).

To check for the isotypes in eggs and embryos, PCR with degenerate primers was performed. A 130-bp band was detected by agarose gel electrophoresis as an amplification product (Fig. 5d, lane 1).

\section{Discussion}

A large number of lectins have been purified from adult fish and classified into various protein families such as P, F, Ctype, mannose-specific, galactose- and N-acetylglucosaminebinding lectins and pentraxins (Kilpatrick 2000; Russel and Lumsden 2005; Endo et al. 2006; Hatanaka et al. 2008). They have been shown in gill, kidney, head kidney, heart, liver, posterior intestine, anterior intestine, stomach and muscle (Kilpatrick 2000; Tsutsui et al. 2003; Russel and Lumsden 2005). In addition, lectins characterized by a broad carbohydrate specificity and ability to bind surfaces of various infectious agents have been detected in phagocytes, plasma and mucosal surfaces (Nakao et al. 2006).

Lectins from the sexual organs and eggs of various species of teleosteans have also been isolated and partially characterized (Hosono et al. 2005). However a major group 

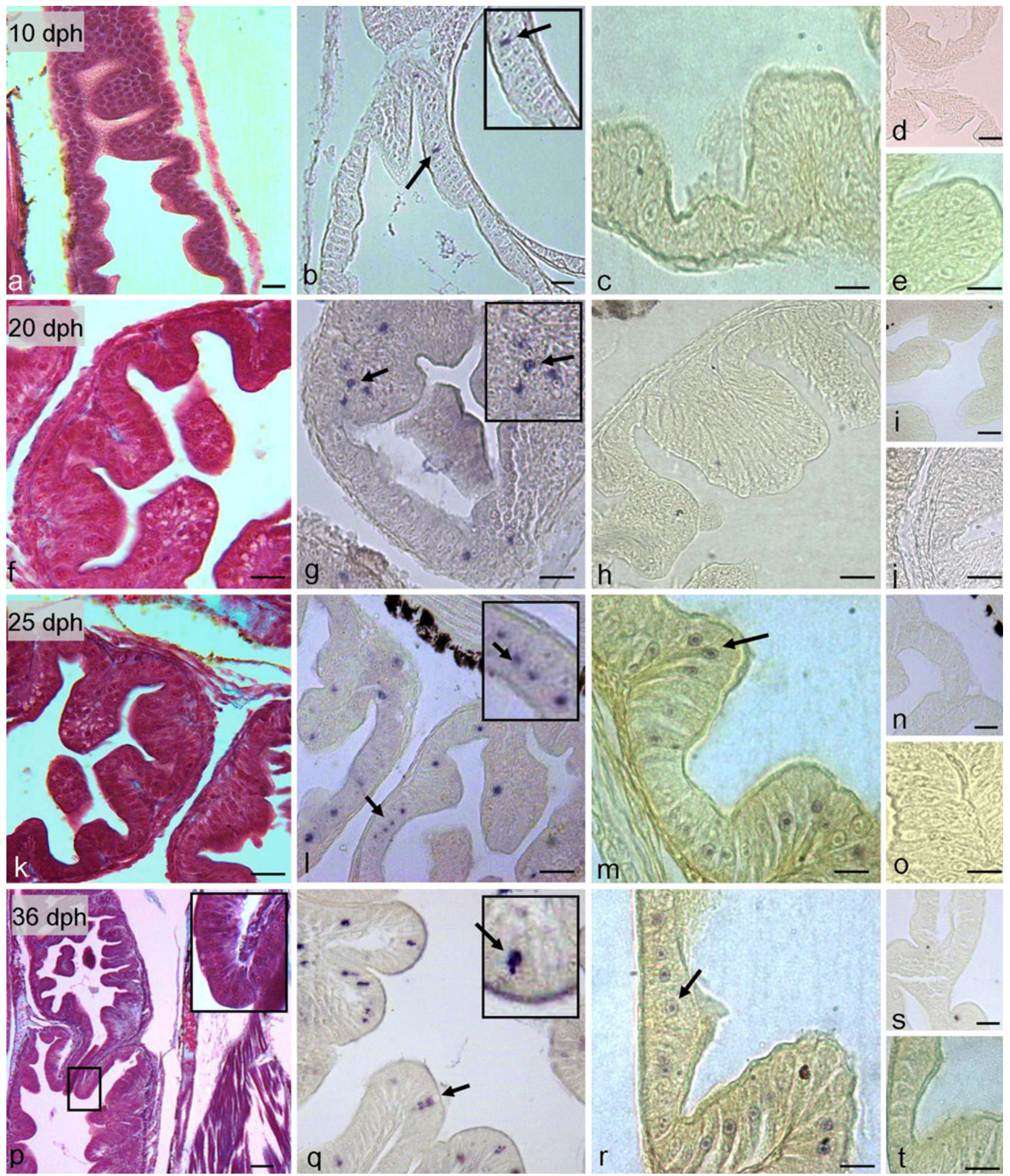

Fig. 2 Gut sections from 10- to 36-dph larval D. labrax. Immunohistochemical staining with anti-DIFBL polyclonal primary antibodies and expression of DIFBL detected by in situ hybridization with singlestrand type DIFBL digoxigenin (DIG)-riboprobe during ontogeny. a, f, $\mathbf{k}, \mathbf{p}$ Gomory stain. Mucocyte cells and columnar epithelium. Inset in p Higher magnification of boxed area. Bars $20 \mu \mathrm{m}$. b, g, l, q Immunohistochemistry with anti-DlFBL primary polyclonal anti- bodies (arrows immunopositive cells). Insets Higher magnifications of immunostained cells. d, i, n, s Controls treated with secondary antibody. Bars $20 \mu \mathrm{m}$. c, h, m, r Treatment with antisense DIFBL DIG-riboprobe (arrows DIFBL-expressing cells stained with antisense DIFBL DIG-riboprobe). No reaction is found in control sections stained with sense DIFBL DIG-riboprobe $(\mathbf{e}, \mathbf{j}, \mathbf{o}, \mathbf{t})$. Bars $40 \mu \mathrm{m}$ 

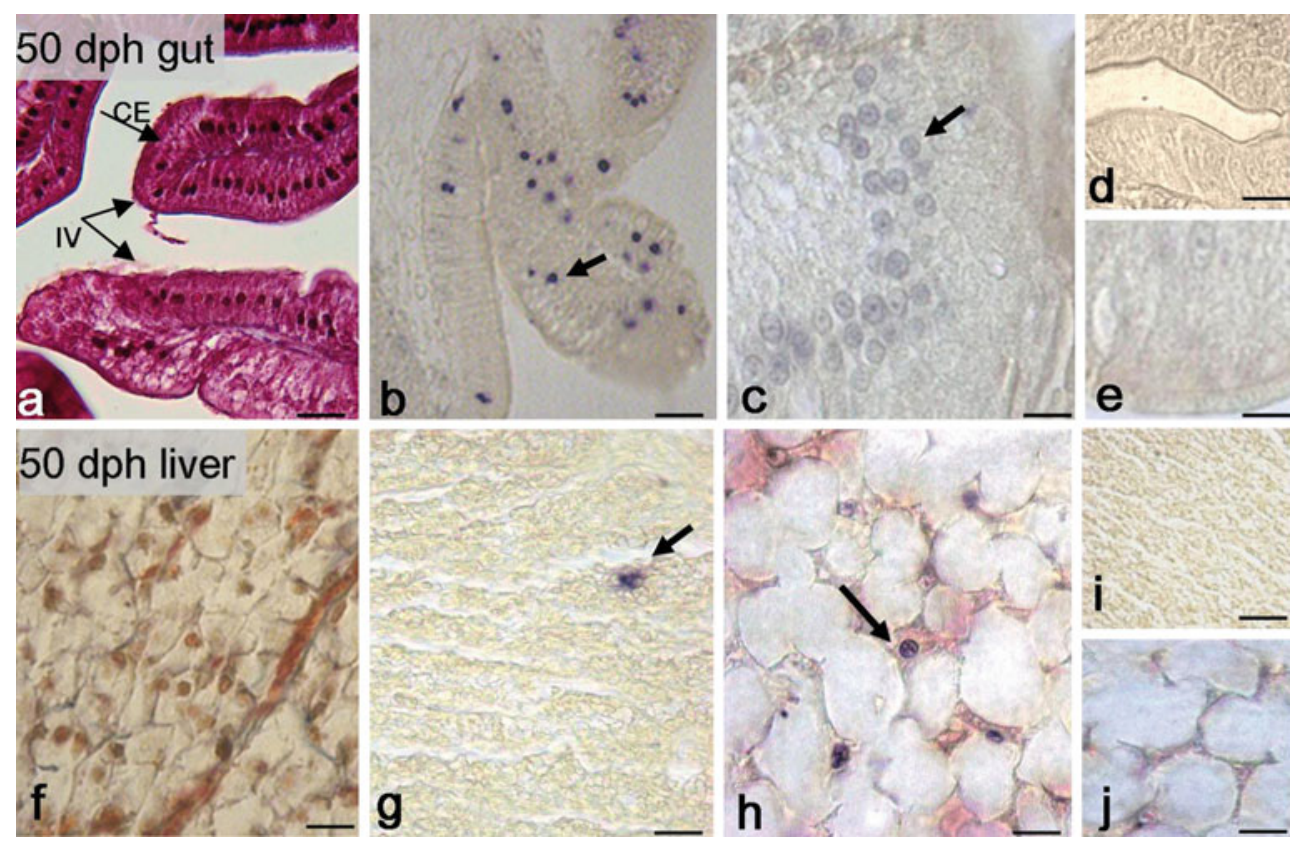

Fig. 3 Gut and liver sections from 50-dph juvenile D. labrax. Immunohistochemical staining with anti-DlFBL polyclonal primary antibodies and expression of DIFBL detected by in situ hybridization with single-strand type DIFBL DIG-riboprobe. a Gomori stain of gut columnar epithelium $(C E)$ and intestinal villi $(I V)$. f Mallory stain of hepatic parenchyma section. b, g Immunohistochemistry with anti-

of fish-egg lectins (purified from Osmerus lanceolatus, Silurus asotus, Oncorhynchus mykiss and Salvelinus leucomaenis) have been designated as rhamnose-binding lectins provided with a tandem repeat domain structure and preferential binding affinity to galactoside sugars (Hosono et al. 2002, 2005; Tateno et al. 2002a, 2002b). These lectins agglutinate Gram-positive and Gram-negative bacteria and bind various structural types of lipopolysaccharide, suggesting a defensive role against microbial invasion (Tateno et al. 2002c). A zebrafish galectin repertoire has been characterized by Ahmed et al. (2004) in oocytes and during embryogenesis suggesting developmentally regulated functions.

We have previously characterized FBLs from Dicentrarchus labrax (DlFBL) and Sparus aurata (SaFBL)
DIFBL primary polyclonal antibodies of gut and liver sections (arrows immunopositive cells). d, i Controls treated with secondary antibody. c, h DIFBL transcript detected in intestinal epithelium and hepatic tissue (arrows) after treatment with antisense DIFBL DIG-riboprobe. No reaction is found in control sections stained with sense DIFBL DIG-riboprobe (e, j). Bars $40 \mu \mathrm{m}$ (gut), $20 \mu \mathrm{m}$ (liver)
Fig. 4 Typical fucose agarose column affinity chromatography profile of extracts of 70-hpf embryos of D. labrax. Peak II eluted with L-fucose $200 \mathrm{mM}$ (open squares absorbance $[\mathrm{Abs}]$ at $280 \mathrm{~nm}$, filled diamonds haemagglutination activity $[H A]$ against rabbit erythrocytes)

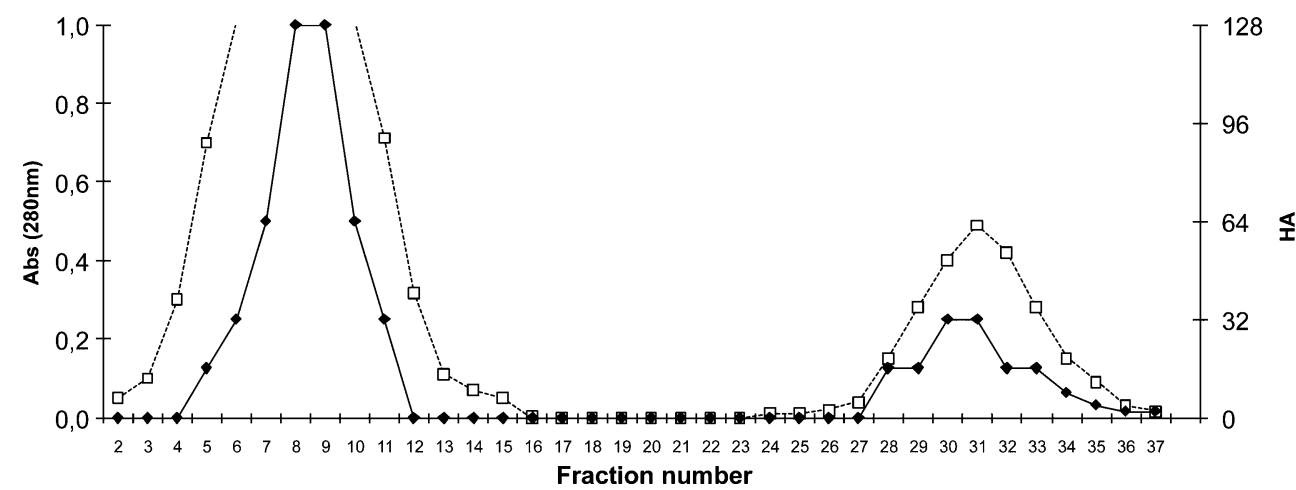




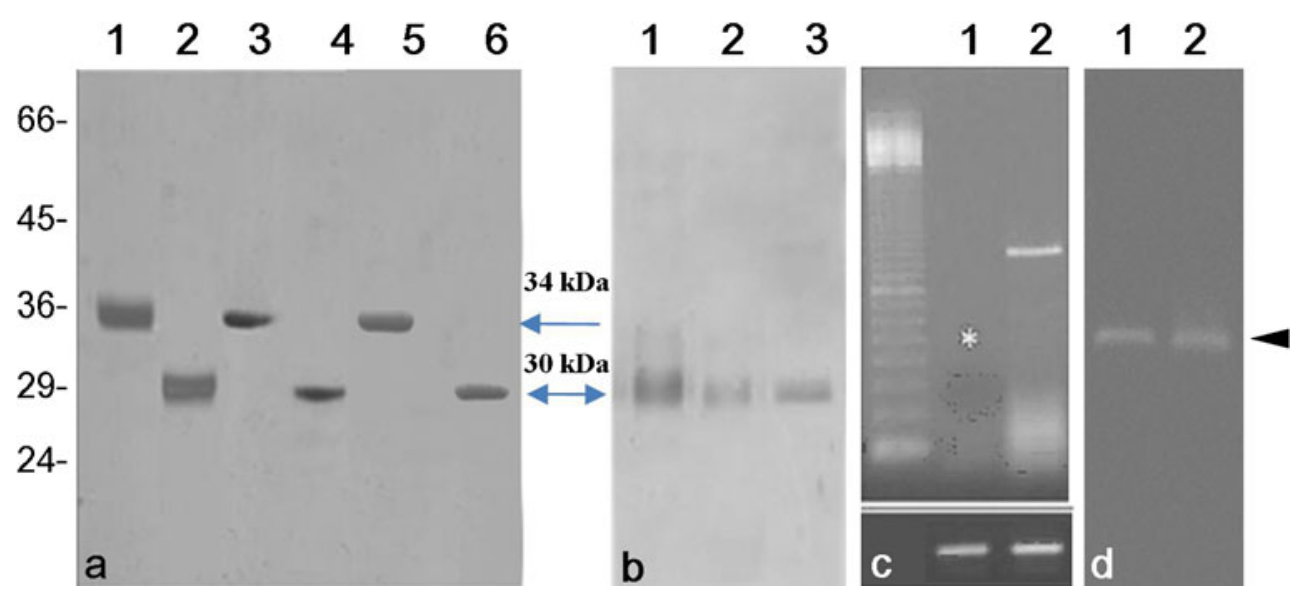

Fig. 5 Electrophoresis of purified lectin from serum of adult $D$. labrax (DIFBL) and from eggs and 70-hpf embryos (EDIFBL). Immunoblotting analysis with anti-DlFBL primary antibodies and detection of DIFBL RNA in eggs by agarose gel electrophoresis and polymerase chain reaction (PCR). a SDS-polyacrylamide gel electrophoresis $(10 \%)$ of DlFBL (lanes 1, 2) and of EDIFBL from embryos (lanes 3, 4) and eggs (lanes 5, 6). Samples under reducing conditions (lanes 1, 3, 5) and under non-reducing conditions (lanes 2, 4, 6). Molecular weights are indicated right. b Immunoblotting of lectins

effect attributable to intrachain disulphide bridges and establishing the similarity of the egg lectin to the serum DIFBL (Cammarata et al. 2001; Salerno et al. 2009). In addition, the isolated lectin from eggs or embryos reacts with antibodies raised against DIFBL. On the contrary, we have been unable to detect any DIFBL mRNA expression in the egg/embryo. However, when degenerate primers are used, a distinct 130-bp band is found. As in previous reports (Odom and Vasta 2006), this finding suggests that lectin isotypes are expressed in eggs and embryos. Whether the lectin fraction isolated from eggs and embryos includes DIFBL of maternal origin is unclear. In this respect, the antibody reaction has identified epitopes in yolk sac components of eggs and 70-hpf embryos. We consider it reasonable to suggest that isotypes and DIFBL share epitopes, although the presence of maternal DIFBL cannot be excluded. The maternal transfer of innate immune factors including the $\mathrm{C} 3$ complement component factor (Magnadottir 2006; Ellingsen et al. 2005; Huttenhuis et al. 2006; Wang et al. 2008, 2009), lectins (Jung et al. 2003; Hanif et al. 2004; Huttenhuis et al. 2006), protease inhibitors (Choi et al. 2002) and lysozymes (Yousif et al. 1991) to the offspring of various teleost species has been reported. Indeed, DIFBLs are probably involved in the protection mechanism. According to Krajhanzl et al. (1984), the lectins released into the perivitelline space can immobilize pathogens. On the other hand, egg lectins might be involved in preventing polyspermy and in development (Nosek et al. 1984; Yousif et al. 1994; Yasumasu 2000; Tateno et al. 2002c). from serum (lane 1), embryos (lane 2) and eggs (lane 3, EDIFBL). Molecular weights are indicated left. $\mathbf{c}$ PCR detection of DIFBL RNA in egg (lane 1) and liver (lane 2) extracts in agarose gel by using specific primers (star absence of bands in egg extract, left lane molecular weight markers). d PCR detection of EDIFBL RNA (arrowhead) in liver (lane 2) and egg (lane 1) extract in agarose gel by using degenerate primers designed from the FBL conserved amino acid sequence in fish

DIFBL is produced by the sea bass larvae at 1 month post-hatching. Notably, DIFBL has been identified in the early intestine of 20-dph larvae, whereas no transcript has been found. Gene expression has been observed only in the gut of 25-dph larva. As in the adult fish, protein and transcript can be identified in the nucleus and cytoplasm of goblet and columnar intestinal cells of the gut absorbent epithelium at the 25- to 36-dph stages.

Finally, in juveniles (50 dph), hepatocytes also produce the lectin suggesting that, at this stage, a systemic role in innate immunity has been reached. In this respect, F-type lectin family members bind L-fucose (Odom and Vasta 2006; Bianchet et al. 2002) as the terminal sugar of a large variety of cell glycans (Staudacher et al. 1999; Chow and Lee 2008). In addition, intestinal cells can be stimulated to produce DlFBL following contacts with indigenous microbial flora or microbial pathogens. The L-fucose-specific opsonizing capacity of adult DIFBL for bacteria targeted for phagocytosis by peritoneal macrophages suggests that this F-lectin mediates immune defence responses both in the intestinal mucus and in the blood stream (Salerno et al. 2009). The possibility thus exists that a similar role can be exerted in juvenile fish.

Further study is needed to analyse the relationships between DIFBL gene sequences from intestinal and hepatic sources and the expression of the gene during disease and to understand the role of this lectin during pathophysiological conditions such as microbial infection. 
Acknowledgements We are grateful to Dr. Rosalinda Di Blasi for her help during the first phase of the immunohistochemical studies and to Mrs. G. Miceli and Mario Guarcello (Department of Animal Biology, University of Palermo) for expert fish maintenance.

\section{References}

Alonso MC, Cano I, Castro D, Perez-Prieto SI, Borrego JJ (2004) Development of an in situ hybridization procedure for the detection of sole aquabirna virus in infected fish cell cultures. J Virol Methods 116:133-138

Ahmed H, Du SJ, O'Leary N, Vasta GR (2004) Biochemical and molecular characterization of galectins from zebrafish (Danio rerio): notochord-specific expression of a prototype galectin during early embryogenesis. Glycobiology 14:219-232

Andersen O, Laursen SB, Svehag SE, Holmoskov U, Thiel S (1991) Mammalian lectins in defence mechanism against microorganism. In: Kilpatrick DC, Van Driessche E, Bog-Hansen TC (eds). Lectin Rev 1:41-52

Arason GJ (1996) Lectins as defence molecules in vertebrates and invertebrates. Fish Shellfish Immunol 6:277-289

Barnabé G (1980) Exposé synoptique des données biologique sur le loup ou bar Dicentrarchus labrax (Linné, 1758). Synopsis FAO Pêches 126:1-70

Bianchet MA, Odom EW, Vasta GR, Amzel LM (2002) A novel fucose recognition fold involved in innate immunity. Nat Struct Biol 9:628-634

Bradford MM (1976) A rapid and sensitive method for the quantitation of microgram quantities of protein utilizing the principle of protein-dye binding. Anal Biochem 72:248-254

Cammarata M, Vazzana M, Chinnici C, Parrinello N (2001) A serum fucolectin isolated and characterized from sea bass Dicentrarchus labrax. Biochim Biophys Acta 1528:196-202

Cammarata M, Benenati G, Odom E, Salerno G, Vizzini A, Vasta G, Parrinello N (2007) Isolation and characterization of a fish F-type lectin from gilt head bream (Sparus aurata) serum. Biochim Biophys Acta 1770:150-155

Choi JH, Park PJ, Kim SK (2002) Purification and characterization of a trypsin inhibitor from the egg of skipjack tuna Katsuwonus pelamis. Fish Sci 68:1367-1373

Chow W, Lee Y (2008) Free fucose is a danger signal to human intestinal epithelial cells. Br J Nutr 99:449-454

Dong CH, Yang ST, Yang ZA, Zhang L, Gui JF (2004) A C-type lectin associated and translocated with cortical granules during oocyte maturation and egg fertilization in fish. Dev Biol 265:341-354

Ellingsen T, Strand C, Monsen E, Bogwald J, Dalmo RA (2005) The ontogeny of complement component $\mathrm{C} 3$ in the spotted wolfish (Anarhichas minor Olafsen). Fish Shellfish Immunol 18:351-358

Endo Y, Takahashi M, Fujita T (2006) Lectin complement system and pattern recognition. Immunobiology 211:283-293

Fock WL, Chen CL, Lam TJ, Sin YM (2000) Isolation and characterisation of a serum lectin from blue gourami, Trichogaster trichopterus (Pallus). Fish Shellfish Immunol 10:489-504

Fock WL, Chen CL, Lam TJ, Sin YM (2001) Roles of an endogenous serum lectin in the immune protection of blue gourami, Trichogaster trichopterus (Pallus) against Aeromonas hydrophila. Fish Shellfish Immunol 11:101-113

Gomori G (1950) A rapid one-step trichrome stain. Am J Clin Pathol 20:661-664

Hanif A, Bakopoulos V, Dimitriadis GJ (2004) Maternal transfer of humoral specific and non-specific immune parameters to sea bream (Sparus aurata) larvae. Fish Shellfish Immunol 17:411-435
Hatanaka A, Umeda N, Hirazawa N (2008) Characterization of highly concentrated serum lectins in spotted halibut Verasper variegates. Parasitology 135:359-369

Hoffmann J, Kafatos A, Janeway CA, Ezekowitz RA (1999) Phylogenetic perspectives in innate immunity. Science 284:1313-1318

Honda S, Kashiwagi M, Miyamoto K, Takei Y, Hirose S (2000) Multiplicity, structure and endocrine and exocrine natures of eel fucose-binding lectins. J Biol Chem 275:33151-33157

Hoover GJ, ElmMowafi A, Simko E, Kocal TE, Ferguson HW, Haves MA (1998) Plasma proteins of raimbow trout (Oncorhynchus mykiss) isolated by binding to lipopolysaccharide from Aeromonas salmonicida. Comp Biochem Physiol 120:559-569

Hosono M, Matsuda K, Kawauchi H, Shiokawa H, Mineki R, Murayama K, Inagawa H (2002) Cloning and characterization of the homolog of mammalian lipopolysaccharide-binding protein and bactericidal permeability-increasing protein in rainbow trout Oncorhynchus mykiss. J Immunol 168:5638-5644

Hosono M, Sugawara S, Ogawa Y, Kohno T, Takayanagi Y, Nitta K (2005) Purification, characterization, cDNA cloning, and expression of asialofetuin-binding C-type lectin from eggs of shishamo smelt (Osmerus [Spirinchus] lanceolatus). Biochim Biophys Acta $1725: 160-173$

Huttenhuis HBT, Grou CPO, Taverne-Thiele AJ, Taverne N, Rombout JHWM (2006) Carp (Cyprinus carpio L.) innate immune factors are present before hatching. Fish Shellfish Immunol 20:586-596

Jung WK, Park PJ, Kim S (2003) Purification and characterization of a new lectin from the hard roe of skipjack tuna, Katsuwonus pelamis. Int J Biochem Cell Biol 35:255-265

Kamiya H, Jimbo M, Yako H, Muramoto K, Nakamura O, Kado R, Watanabe T (2002) Participation of the C-type hemolymph lectin in mineralization of the acorn barnacle Megabalanus rosa. Mar Biol 140:1235-1240

Kilpatrick DC (2000) Handbook of animal lectins, properties and biomedical applications. Wiley, Chichester

Kilpatrick DC (2002) Animal lectins: a historical introduction and overview. Biochim Biophys Acta 1572:187-197

Krajhanzl A, Nosek J, Habrová V, Kocourek J (1984) An immunofluorescence study on the occurrence of endogenous lectins in the differentiating oocytes of silver carp (Hypophthalmichthys molitrix Valenc.) and tench (Tinca tinca L.). Histochem $\mathrm{J}$ $16: 432-434$

Laemmli UK (1970) Cleavage of structural proteins during the assembly of the head of bacteriophage T4. Nature 227:680-685

Mallory FB (1936) Pathological technique. Saunders, Philadelphia

Magnadottir B (2006) Innate immunity of fish (overview). Fish Shellfish Immunol 20:137-151

Nakao M, Kajiya T, Sato Y, Somamoto T, Kato-Unoki Y, Matsushita M, Nakata M, Fujita T, Yano T (2006) Lectin pathway of bony fish complement: identification of two homologs of the mannosebinding lectin associated with MASP2 in the common carp (Cyprinus carpio). J Immunol 177:5471-5479

Nosek J, Krajhanzl A, Kocourek J (1984) Binding of the cortical granule lectin to the jelly envelope in mature perch ova. Histochem $\mathrm{J}$ $16: 429-431$

Odom E, Vasta G (2006) Characterization of a binary tandem domain F-type lectin from striped bass (Morone saxatilis). J Biol Chem 281:1698-1673

Ottinger CA, Johonson SC, Ewart KV, Brown LL, Rosa NW (1999) Enhancement of anti-Aeromonas salmonicida activity in Atlantic salmon (Salmo sellar) macrophages by a mannose-binding lectin. Comp Biochem Physiol 123C:53-59

Russel S, Lumsden JS (2005) Function and heterogeneity of fish lectins. Vet Immunol Immunopathol 108:111-120

Salerno G, Parisi MG, Parrinello D, Benenati G, Vizzini A, Vazzana M, Vasta GR, Cammarata M (2009) F-type lectin from the sea bass (Dicentrarchus labrax): purification, cDNA cloning, tissue 
expression and localization, and opsonic activity. Fish Shellfish Immunol 27:143-153

Sharon N, Lis H (2004) History of lectins: from hemagglutinins to biological recognition molecules. Glycobiology 14:53-62

Staudacher E, Altmann F, Wilson IB, Marz L (1999) Fucose in N-glycans: from plant to man. Biochim Biophys Acta 1473:216236

Suzuki Y, Tasumi S, Tsutsui S, Okamoto M, Suetake H (2003) Molecular diversity of skin mucus lectins in fish. Comp Biochem Physiol 136:723-730

Tateno H, Yamaguchia T, Ogawa T, Muramoto $\mathrm{K}$, Watanabe $\mathrm{T}$, Kamiya H, Saneyoshi M (2002a) Immunohistochemical localization of rhamnose-binding lectins in the steelhead trout (Oncorhynchus mykiss). Dev Comp Immunol 26:543-550

Tateno H, Ogawa T, Muramoto K, Kamiya H, Saneyoshi M (2002b) Distribution and molecular evolution of rhamnose-binding lectins in Salmonidae: isolation and characterization of two lectins from whitespotted Charr (Salvelinus leucomaenis) eggs. Biosci Biotechnol Biochem 66:1356-1365

Tateno H, Ogawa T, Muramoto K, Kamiya H, Saneyoshi M (2002c) Rhamnose-binding lectins from eggs from steelhead trout (Oncorhynchus mykiss) eggs recognize bacterial lipopolysaccharides and lipoteichoic acid. Biosci Biotechnol Biochem 66: 604-612

Thompson SW (1966) Selected histochemical and histopathological methods. Thomas, Springfield, p 794
Tsutsui S, Tasumi S, Suetake H, Suzuki Y (2003) Lectins homologous to those of monocotyledonous plants in the skin mucus and intestine of pufferfish, Fugu rubripes. J Biol Chem 278:20882-20889

Turner MW (1996) Mannose binding lectin: the pluripotent molecule of the innate immune system. Immunol Today 17:532-540

Vasta GR, Ahmed H, Odom EW (2004) Structural and functional diversity of lectin repertoires in invertebrates, protochordates and ectothermic vertebrates. Curr Opin Struct Biol 11:53-62

Wang ZP, Zhang SC, Wang GF, An Y (2008) Complement activity in the egg cytosol of zebrafish Danio rerio: evidence for the defense role of maternal complement components. PLoS ONE 3:e1463

Wang ZP, Zhang S, Tong Z, Li L, Wang G (2009) Maternal transfer and protective role of the alternative complement components in zebrafish Danio rerio. PLoS ONE 4:e4498

Wassarman PM (1987) The biology and chemistry of fertilization. Science 235:553-560

Weigert K (1904) Eine kleine Verbesserung der Hämatoxylin vanGieson-Methode. Z Wiss Mikrosk Mikrosk Tech 21:1-5

Yasumasu S (2000) Salmon egg lectin and its sperm agglutination activity. Sophia Life Sci Bull 18:45-52

Yousif AN, Albright LJ, Evelyn TPT (1991) Occurrence of lysozyme in the eggs of coho salmon Oncorhynchus kisutch. Dis Aquat Org $10: 45-49$

Yousif AN, Albright LJ, Evelyn TPT (1994) In vitro evidence for the antibacterial role of lysozyme in salmonid eggs. Dis Aquat Org 19:15-19 